\title{
Effect of blood serum enzymes on meat qualities of piglet productivity
}

\author{
V. Khalak ${ }^{1 *}$, B. Gutyj ${ }^{2}$, O. Bordun ${ }^{3}$, M. Ilchenko ${ }^{4}$, A. Horchanok ${ }^{5}$ \\ ${ }^{1}$ State Institution Institute of Grain Crops of NAAS, Dnipro, Ukraine \\ ${ }^{2}$ Stepan Gzhytskyi National University of Veterinary Medicine and Biotechnologies Lviv, Ukraine \\ ${ }^{3}$ Institute of Agriculture of Northern East of National Academy of Agrarian Sciences of Ukraine, \\ Sumy, Ukraine \\ ${ }^{4}$ Institute of pig breeding and agroindustrial production, Poltava, Ukraine \\ ${ }^{5}$ Dnipro State University of Agriculture and Economics, Dnipro, Ukraine
}

*Corresponding author E-mail: v16kh91@gmail.com

\section{Received: 29.12.2019. Accepted 15.02.2020}

\begin{abstract}
The article presents the results of studies of fattening and meat qualities of young white pigs of different white breeds of different intensity of formation $(\Delta \mathrm{t})$ in early ontogeny, biochemical parameters of blood serum (aspartate aminotransferase activity, alanine aminotransferase, alkaline transferase, alkaline phosphatase. It is established that according to the main indicators of fattening and meat qualities (age of reaching live weight of $100 \mathrm{~kg}$, days; thickness of the sleeve at the level of 6-7 thoracic vertebrae, mm; length of chilled carcass, $\mathrm{mm}$ ) young pigs of the controlled herd belong to the first class and class elite, and serum biochemical parameters are consistent with the physiological norm of clinically healthy animals. Taking into account the class of distribution by intensity of formation $(\Delta \mathrm{t})$, a significant difference was established between animals of I $(\Delta t=0.795-0.832)$ and III $(\Delta t=0.660-$ 0.703) groups on the average daily gain of live weight and age of reaching live weight of $100 \mathrm{~kg}$. The relationship between the biochemical parameters of serum, fattening and meat characteristics of young pigs ranges from -0.250 to +0.385 and is unlikely. We offer in breeding and breeding work, along with the traditional methods of evaluation and selection of high-yielding animals use the method of evaluation and breeding indices.
\end{abstract}

Keywords: Young pigs; Breed; Ontogeny; Intensity of formation; Fattening and meat quality; Biochemical parameters of blood serum; Variability; Correlation

\section{Introduction}

The analysis of the results of studies of domestic and foreign scientists, as well as the experience of modern agro-formations show that important indicators, along with the reproductive capacity of sows and boars, are offspring and meat qualities of their offspring (Birta \& Burhu, 2012; Berezovskyi, 2014; Bankovska \& Voloshchuk, 2015; Agapova \& Susol, 2015; Berezovskyi et al., 2016; Bankovska, 2016; Vashchenko, 2016; Khalak et al., 2019). However, these groups of features in domestic animals do not provide a high level of profitability of the industry as a whole. This is due to the lack of adequate conditions for the keeping and feeding of animals of different sex age groups, uncontrolled import of foreign livestock, lack of regional pig breeding and hybridization programs and other factors (Orzechowskal et al., 2006; Koval, 2014; Susol, 2013; 2014).

An important issue is the study of the nature of inheritance of the main quantitative traits of young pigs, taking into account the growth rates in early ontogeny and interior (Jejdrigevich \& Raevskaja, 1966; Shejko et al., 2013; Povod, 2014; Loban \& Shejko, 2015). The aim of the study is to investigate the fattening and meat qualities of young white pigs of different breeding intensity $(\Delta t)$ in early ontogeny, serum biochemical parameters (aspartate aminotransferase (AST) activity, alanine aminotransferase (ALT), alkaline phosphatase (alkaline phosphatase) pair correlation coefficients between traits.

\section{Material and Methods}

The study was conducted under the conditions of a breeding reproducer for breeding pigs of large white breed LLC "AF "Dzerzhynets" of Dnipropetrovsk region, research center of biosafety and environmental control of APC resources of Dnepropetrovsk State Agrarian and Economic University, meat-packing plant "Globinsky Meat Combine" LLC and livestock laboratories of the State Institution "Institute of Crops of NAAS". The subject of the study was young pigs of large white breed. Control fattening of animals was carried out in the conditions of the economy in accordance with conventional methods (Berezovskyi \& Khatko, 2005). The following absolute and integrated indicators were taken into account for estimation of young pigs for fattening and meat qualities: "average daily weight gain for the period of control fattening, $\mathrm{g}$ ", "age of reaching live weight of $100 \mathrm{~kg}$, days", meat quality of young pigs was investigated for the thickness of the pelvis at the level of 6-7 thoracic vertebrae (mm) and the length of the cooled carcass (cm). Integrated assessment of growth, fattening and meat quality of pigs was performed using the following mathematical models: 
$\Delta t=\frac{W_{3}-W_{0}}{0,5 \times\left(W_{3}+W_{0}\right)}-\frac{W_{6}-W_{3}}{0,5 \times\left(W_{6}+W_{0}\right)}$,

where: $\Delta t$ - index "intensity of formation", score; W0, W3, W6 - live weight of young pigs at the appropriate age - at birth, at 3 and 6 months of age, kg. (Svechin, 1985);

$I_{\theta}=100+(242 \times K)-(4,13 \times L)$,

where: IB - complex index of fattening and meat quality, points (index of B. Taylor, 1996); $\mathrm{K}$ is the average daily increase in live weight, $\mathrm{kg} ; \mathrm{L}-$ thickness of the sleeve at the level of $6-7$ thoracic vertebrae, $\mathrm{mm} ; 242 ; 4.13$ - constant coefficients (Berezovskyi, 1999). Blood samples were taken at 5 months of age. Blood biochemical studies were performed using the sets of reagents of the firm "Phyllis-Diagnostics" (Ukraine, Dnipro). The activity of aspartate aminotransferase (AST), alanine aminotransferase (ALT) and alkaline phosphatase was investigated in the blood serum of pigs (Vlizlo et al., 2012). Biometric processing of research results was carried out according to the method of G.F. Lakin (Lakin, 1985) using the programmatic module "Data Analysis" in Microsoft Excel.

\section{Results and Discussion}

It is established that young pigs of large white breed of the controlled herd are characterized by sufficiently high indicators of fattening and meat qualities. Thus, the average daily gain of live weight during the period of control fattening was $805.3 \pm 6.15 \mathrm{~g}$ $(\mathrm{Sv} \pm \mathrm{SCv}=3.82 \pm 0.493 \%)$, the age of reaching the live weight of $100 \mathrm{~kg}-175.8 \pm 1.15$ days (Sv $\pm \mathrm{SCv}=3.28 \pm$ $0.423 \%)$, the thickness of the sleeve at the level of 6-7 thoracic vertebrae, $\mathrm{mm}-22.3 \pm 0.47 \mathrm{~mm}(\mathrm{Cv} \pm \mathrm{SCv}=10.64 \pm$ $1.374 \%)$, the length of the cooled carcass is $96.3 \pm 0.31 \mathrm{~cm} \mathrm{(Cv} \pm \mathrm{SCv}=1.63 \pm 0.210 \%)$. Integrated growth $(\Delta \mathrm{t})$, fattening and meat (Iv) values are $0.748 \pm 0.010(\mathrm{~Sv} \pm \mathrm{SCv}=7.23 \pm 0.934 \%)$ and $202.55 \pm 2.231$ points $(\mathrm{Sv} \pm \mathrm{SCv}=5.51 \pm$ $0.711 \%)$ respectively. Biochemical parameters of blood serum correspond to the physiological norm of clinically healthy animals: aspartate aminotransferase (AST) activity was $1.33 \pm 0.074 \mathrm{mmol} / \mathrm{h} / \mathrm{l}(\mathrm{Sv} \pm \mathrm{SCv}=27.65 \pm 3.722 \%)$, alanine aminotransferase $(\mathrm{ALT})-1.87 \pm 0.063 \mathrm{mmol} / \mathrm{h} / \mathrm{l}(\mathrm{Sv} \pm \mathrm{SCv}=17.03 \pm 2.201 \%)$, alkaline phosphatase $-291.99 \pm 12.517 \mathrm{u} / \mathrm{l}(\mathrm{Sv} \pm \mathrm{SCv}=$ $21.43 \pm 2.768 \%)$. The results of studies of biochemical parameters of serum, fattening and meat characteristics of young white pigs of different growth rates in early ontogeny are given in Tables 1 and 2.

Table 1. Biochemical parameters of blood serum of young white pigs of different growth rates in early ontogenesis, $n=10$

\begin{tabular}{|c|c|c|c|c|}
\hline \multirow[b]{2}{*}{ Indicators, units } & \multirow[b]{2}{*}{$\begin{array}{l}\text { Biometric } \\
\text { indicators }\end{array}$} & \multicolumn{3}{|c|}{ Formation intensity $(\Delta t)$, score } \\
\hline & & $\begin{array}{c}0.795-0.832 \\
\text { I }\end{array}$ & $\begin{array}{c}0.713-0.769 \\
\text { Group } \\
\text { II }\end{array}$ & $\begin{array}{c}0.660-0.703 \\
\text { III }\end{array}$ \\
\hline & $\bar{X} \pm S \bar{x}$ & $1.21 \pm 0.107$ & $1.43 \pm 0.142$ & $1.32 \pm 0.073$ \\
\hline ASI dCUVICy, IIIIIOI/II/L & $C v \pm S_{C v}, \%$ & $25.1 \pm 5.62$ & $33.0 \pm 7.38$ & $13.6 \pm 3.04$ \\
\hline ALT activity, $\mathrm{mmol} / \mathrm{h} / \mathrm{L}$ & $\begin{array}{c}\bar{X} \pm S \bar{x} \\
C v \pm S_{C v} \%\end{array}$ & $\begin{array}{c}1.80 \pm 0.119 \\
18.7 \pm 4.19\end{array}$ & $\begin{array}{c}1.96 \pm 0.104 \\
17.6 \pm 3.95\end{array}$ & $\begin{array}{c}1.79 \pm 0.095 \\
13.0 \pm 2.91\end{array}$ \\
\hline Index de Ritis (AST/ALT ratio) & $\begin{array}{c}\bar{X} \pm S \bar{x} \\
C v \pm S_{C v} \%\end{array}$ & $\begin{array}{l}0.68 \pm 0.081 \\
33.4 \pm 7.47\end{array}$ & $\begin{array}{c}0.73 \pm 0.063 \\
28.6 \pm 6.39\end{array}$ & $\begin{array}{c}0.74 \pm 0.045 \\
14.9 \pm 3.34\end{array}$ \\
\hline $\begin{array}{l}\text { Activity of alkaline phosphatase, } \\
\text { units/L. }\end{array}$ & $\begin{array}{c}\bar{X} \pm S \bar{x} \\
C v \pm S_{C v}, \%\end{array}$ & $296.1 \pm 28.46$ & $288.3 \pm 12.73$ & $\begin{array}{l}293.1 \pm 31.89 \\
26.64 \pm 5.959\end{array}$ \\
\hline
\end{tabular}

Table 2. Breeding and meat characteristics of pigs of white big breed at different intensity of early ontogenesis forming, $\mathrm{n}=10$.

\section{Indicators, units}

Average daily increase in live weight during the period of control fattening, $g$

Age of live weight $100 \mathrm{~kg}$, days

Thickness at 6-7 thoracic vertebrae, $\mathrm{mm}$

The length of the cooled carcass, $\mathrm{cm}$

Comprehensive index of fattening and meat quality, points

Note: ${ }^{*}-P<0.05 ; * *-P<0.001$

\section{Formation intensity $(\Delta t)$, score}

\section{Biometric indicators}

$\begin{array}{cc}\bar{X} \pm S \bar{x} & 812.6 \pm 5.30 \\ C v \pm S_{C v}, \% & 1.84 \pm 0.411 \\ \bar{X} \pm S \bar{x} & 171.2 \pm 0.87 \\ C v \pm S_{C v}, \% & 1.43 \pm 0.319 \\ \bar{X} \pm S \bar{x} & 21.2 \pm 0.95 \\ C v \pm S_{C v}, \% & 12.76 \pm 2.854 \\ \bar{X} \pm S \bar{x} & 96.2 \pm 0.70 \\ C v \pm S_{C v}, \% & 2.05 \pm 0.458 \\ \overline{\mathrm{X}} & 208.95\end{array}$

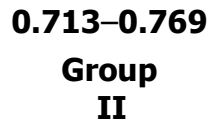

$804.5 \pm 10.41$

$4.29 \pm 0.959$

$176.7 \pm 1.62$

$3.05 \pm 0.682$

$23.0 \pm 0.64$

$9.32 \pm 2.085$

$96.2 \pm 0.42$

$1.47 \pm 0.328$
$0.660-0.703$

\section{III}

$779.1 \pm 12.73$

$4.85 \pm 1.085$

$178.7 \pm 1.79$

$3.24 \pm 0.724$

$22.6 \pm 0.88$

$9.53 \pm 4.545$

$96.3 \pm 0.61$

$1.56 \pm 0.348$
199.57

195.18 
The difference between the de Ritis groups (AST/ALT) and the alkaline phosphatase activity ranged from 0.98 to $8.11 \%$ and is unlikely. Studies of the fattening and meat characteristics of young white pigs of different intensities of early ontogeny formation indicate that animals of group I were characterized by higher rates of average daily live weight gain and complex index of fattening and meat characteristics. According to these indicators, they outperformed peers of II and III groups by 8.1 (td $=0.69 ; \mathrm{P}>0.05$ ) and $33.5 \mathrm{~g}(\mathrm{td}=2.43 ; \mathrm{P}<0.05), 9.18$ and 10.6 points. Higher daily average weight gain contributed to a reduction in age of $100 \mathrm{~kg}$ live weight by $5.5(\mathrm{td}=1.83 ; \mathrm{P}>0.05)-7.5$ days $(\mathrm{td}=3.76 ; \mathrm{P}<0.001)$. The thickness of the pelvis at the level of $6-7$ thoracic vertebrae and the complex index of fattening qualities the difference between the animals of these groups was 1.8 (td $=1.57$; $\mathrm{P}>0.05)-1.4 \mathrm{~mm}(\mathrm{td}=1.08 ; \mathrm{P}>0.05), 9.38-13.77$ points. The length of the chilled carcass in animals of the I-III groups ranged from 96.2 to $96.3 \mathrm{~cm}$, which corresponds to the elite class, according to the Instruction on pig testing.

The results of the calculation of the pair correlation coefficients between the interior, fattening and meat qualities showed that the number of direct and feedback relationships is 40.0 and $60.0 \%$ (Table 3 ).

Table 3. The coefficient of paired correlation between biochemical parameters of blood serum, fattening and meat characteristics of large white breed, $\mathrm{n}=25$.

\begin{tabular}{|c|c|c|c|}
\hline \multicolumn{2}{|l|}{ Indicator } & \multicolumn{2}{|c|}{ Biometric indicators } \\
\hline$x$ & $\boldsymbol{y}$ & $r \pm S_{r}$ & $\mathbf{t}_{\mathbf{r}}$ \\
\hline \multirow{4}{*}{$\begin{array}{l}\text { Average daily increase in live weight } \\
\text { during the period of control fattening, } g\end{array}$} & $\mathrm{a}$ & $0.239 \pm 0.2015$ & 1.18 \\
\hline & $b$ & $0.385 \pm 0.1924$ & 2.00 \\
\hline & $\mathrm{C}$ & $-0.150 \pm 0.2062$ & 0.73 \\
\hline & $\mathrm{a}$ & $-0.004 \pm 0.2085$ & 0.02 \\
\hline \multirow[t]{3}{*}{ Age of live weight $100 \mathrm{~kg}$ obtaining, days } & $b$ & $-0.250 \pm 0.2019$ & 1.24 \\
\hline & c & $-0.017 \pm 0.2085$ & 0.08 \\
\hline & a & $-0.053 \pm 0.2082$ & 0.25 \\
\hline \multirow[t]{3}{*}{ Thickness at 6-7 thoracic vertebrae, $\mathrm{mm}$} & $\mathrm{b}$ & $-0.069 \pm 0.2080$ & 0.33 \\
\hline & C & $-0.002 \pm 0.2085$ & 0.01 \\
\hline & a & $0.090 \pm 0.2077$ & 0.43 \\
\hline \multirow[t]{3}{*}{ The length of the cooled carcass, $\mathrm{cm}$} & $\mathrm{b}$ & $0.338 \pm 0.1962$ & 1.72 \\
\hline & $\mathrm{c}$ & $-0.039 \pm 0.2084$ & 0.19 \\
\hline & $\mathrm{a}$ & $0.207 \pm 0.2040$ & 1.01 \\
\hline \multirow{2}{*}{$\begin{array}{l}\text { Comprehensive index of fattening and } \\
\text { meat quality }\end{array}$} & $b$ & $0.318 \pm 0.1977$ & 1.61 \\
\hline & $\mathrm{C}$ & $-0.099 \pm 0.2075$ & 0.48 \\
\hline
\end{tabular}

Note: a - activity of $A S T, \mathrm{mmol} / \mathrm{h} / \mathrm{L}, \mathrm{b}$ - activity of $A L T, \mathrm{mmol} / \mathrm{h} / \mathrm{L}, \mathrm{c}$ - activity of alkaline phosphatase, units/l, * $-P>0.95$

They range from $-0.250 \pm 0.2019$ (100 kg life weight $\times$ ALT activity to $0.385 \pm 0.1924$ (mean daily live weight gain during control fattening $\times$ ALT activity).

\section{Conclusion}

Biochemical parameters of blood serum of young pigs correspond to the physiological norm of clinically healthy animals, fattening and meat quality - class and class elite. The probable difference between the animals of the first and third groups is set according to the indicators of "average daily weight gain for the period of control fattening, $\mathrm{g}$ " and "age of reaching the live weight of $100 \mathrm{~kg}$, days". The coefficients of paired correlation between biochemical parameters of blood serum, fattening and meat characteristics of large white breed range from -0.250 to +0.385 . We offer in breeding and breeding work, along with traditional methods of evaluation and selection of high-performance animals to use the method of evaluation and breeding indices.

\section{References}

Ahapova, Ye. M., \& Susol, R. L. (2015). Kharakterystyka svynei zavodskoho typu Prychornomorskyi za vidhodivelnymy ta miasnymy yakostiamy. Rozvedennia i henetyka tvaryn, 49, 57-62 (in Ukrainian).

Bankovska, I. B. (2016). Kompleksnyi vplyv faktoriv porody, stati ta zhyvoi masy na pokaznyky miasnoi produktyvnosti svynei. Visnyk Sumskoho natsionalnoho ahrarnoho universytetu. Seriia: Tvarynnytstvo, 7, 36-42 (in Ukrainian).

Bankovska, I. B., \& Voloshchuk, V. M. (2015). Vplyv faktoriv henotypu ta sposobu utrymannia na morfolohichnyi sklad tush. Visnyk ahrarnoi nauky Prychornomoria, 2(84), 91-99 (in Ukrainian).

Berezovskyi, M. D. (1999). Stan i perspektyvy selektsii svynei velykoi biloi porody v Ukraini. Visnyk ahrarnoi nauky, 10, 49-52 (in Ukrainian). Berezovskyi, M. D. (2014). Problemni pytannia z udoskonalennia pleminnoho svynarstva v Ukraini ta yikh vyrishennia. Svynarstvo: mizhvidomchyi tematychnyi naukovyi zbirnyk Instytutu svynarstva i APV NAAN, 64, 37-48 (in Ukrainian).

Berezovskyi, M. D., Onishchenko, A. O., \& Vashchenko, P. A. (2016). Otsinka vidhodivelnykh i miasnykh yakostei svynei velykoi biloi porody zavodskoho typu "Bahachanskyi". Svynarstvo: mizhvidomchyi tematychnyi naukovyi zbirnyk Instytutu svynarstva i APV NAAN, 68, 40-47 (in Ukrainian).

Birta, H. O., \& Burhu, Yu. H. (2012). Formuvannia miaso-salnoi produktyvnosti riznykh henotypiv svynei. Visnyk Poltavskoi derzhavnoi ahrarnoi akademii, 2, 108-112 (in Ukrainian).

Birta, H. O., \& Burhu, Yu. H. (2012). Vidhodivelni, zabiini ta miaso-salni yakosti svynei riznykh napriamiv produktyvnosti. Visnyk Poltavskoi derzhavnoi ahrarnoi akademii, 4, 49-51 (in Ukrainian).

Boyko, O. O., Gugosyan, Y. A., Shendrik, L. I., \& Brygadyrenko, V. V. (2019). Intraspecific morphological variation in free-living stages of Strongyloides papillosus (Nematoda, Stronfyloididae) parasitizing various mammal species. Vestnik Zoologii, 53(4), 313-324. doi: 10.2478/vzoo-2019-0030. 
Gutyj, B. V., Ostapyuk, A. Y., Sobolev, O. I., Vishchur, V. J., Gubash, O. P., Kurtyak, B. M, Kovalskyi, Y. V., Darmohray, L. M., Hunchak, A. V., Tsisaryk, O. Y., Shcherbatyy, A. R., Farionik, T. V., Savchuk, L. B., Palyadichuk, O. R., \& Hrymak, K. (2019). Cadmium burden impact on morphological and biochemical blood indicators of poultry. Ukrainian Journal of Ecology, 9(1), 236-239.

Gutyj, B., Grymak, Y., Drach, M., Bilyk, O., Matsjuk, O., Magrelo, N., Zmiya, M., \& Katsaraba, O. (2017). The impact of endogenous intoxication on biochemical indicators of blood of pregnant cows. Regulatory Mechanisms in Biosystems, 8(3), 438-443. doi: $10.15421 / 021768$

Gutyj, B., Grymak, Y., Hunchak, V., Mysak, A., Nazaruk, N., Brezvyn, O., Hariv, I., Shcherbatyy, A., Semeniv, B., Bushueva, I., Parchenko, V., \& Kaplaushenko, A. (2018). Preclinical searches of the preparation Thireomagnile. Ukrainian Journal of Ecology, 8(1), 688-695. doi: 10.15421/2018_267

Gutyj, B., Khariv, I., Binkevych, V., Binkevych, O., Levkivska, N., Levkivskyj, D., \& Vavrysevich, Y. (2017). Research on acute and chronic toxity of the experimental drug Amprolinsyl. Regulatory Mechanisms in Biosystems, 8(1), 41-45. doi: 10.15421/021708.

Gutyj, B., Leskiv, K., Shcherbatyy, A., Pritsak, V., Fedorovych, V., Fedorovych, O., Rusyn, V., \& Kolomiiets, I. (2017). The influence of Metisevit on biochemical and morphological indicators of blood of piglets under nitrate loading. Regulatory Mechanisms in Biosystems, 8(3), 427-432. doi: 10.15421/021766

Gutyj, B., Leskiv, K., Shcherbatyy, A., Pritsak, V., Fedorovych, V., Fedorovych, O., Rusyn, V., \& Kolomiiets, I. (2017). The influence of Metisevit on biochemical and morphological indicators of blood of piglets under nitrate loading. Regulatory Mechanisms in Biosystems, 8(3), 427-432. doi: 10.15421/021766.

Gutyj, B., Martyshchuk, T., Bushueva, I., Semeniv, B., Parchenko, V., Kaplaushenko, A., Magrelo, N., Hirkovyy, A., Musiy, L., \& Murska, S. (2017). Morphological and biochemical indicators of blood of rats poisoned by carbon tetrachloride and subject to action of liposomal preparation. Regulatory Mechanisms in Biosystems, 8(2), 304-309. doi:10.15421/021748.

Gutyj, B., Nazaruk, N., Levkivska, A., Shcherbatyj, A., Sobolev, A., Vavrysevych, J., Hachak, Y., Bilyk, O., Vishchur, V., \& Guta, Z. (2017). The influence of nitrate and cadmium load on protein and nitric metabolism in young cattle. Ukrainian Journal of Ecology, 7(2), 9-13.

Holovakha, V. I., Piddubnyak, O. V., Bakhur, T. I., Vovkotrub, N. V., Antipov, A. A., Anfiorova, M. V., Gutyj, B. V., Slivinska, L. G., Kurdeko, O. P., \& Macynovich, A. O. (2018). Changes in erythrocytopoesis indices in dogs with babesiosis. Regulatory Mechanisms in Biosystems, 9(3), 379-383. doi:10.15421/02185

Instruktsiia z bonituvannia svynei; Instruktsiia z vedennia pleminnoho obliku u svynarstvi. K.: "Kyivskyi universytet" (in Ukrainian).

Jejdrigevich, E. V., \& Raevskaja, V. V. (1966). Inter'er sel'skohozjajstvennyh zhivotnyh. M.: Kolos (in Russian).

Khalak, V.I., Gutyj, B.V., \& Stadnits'ka, O.I. (2019). Feeding and meat qualities of young pigs of different origin and intensity of formation in early ontogenesis. Scientific Messenger of Lviv National University of Veterinary Medicine and Biotechnologies. Series: Agricultural sciences, 21(91), 10-15. doi: 10.32718/nvlvet-a9102

Kisera Ya.V., Storchak Yu.G., Gutyj B.V., Bozhyk L.Ya., Magrelo N., Sus Y., Dashkovskyy O., Pryimych V.I., Vus U., Kit L., \& Sachuk R. (2019). Structural and functional features of the vermiform appendix at the tissue and cellular levels in rabbits after the introduction of immunobiological drugs. Ukrainian Journal of Ecology, 9(2), 217-226.

Koval, Yu. A. (2014). Vplyv umov utrymannia, henotypu ta sezonu roku na vidhodivelni pokaznyky produktyvnosti svynei. Svynarstvo : mizhvidomchyi tematychnyi naukovyi zbirnyk Instytutu svynarstva i APV NAAN, 64, 165-169 (in Ukrainian).

Kulyaba, O., Stybel, V., Gutyj, B., Turko, I., Peleno, R., Turko, Ya., Golovach, P., Vishchur, V., Prijma, O., Mazur, I., Dutka, V., Todoriuk, V., Golub, O. Dmytriv, O., \& Oseredchuk, R. (2019). Effect of experimental fascioliasis on the protein synthesis function of cow liver. Ukrainian Journal of Ecology, 9(4), 612-615.

Lakin, G. F. (1985). Biometrija. Moskva (in Russian).

Loban, N. A., \& Shejko, I. P. (2015). Formoobrazujushhij process v svinovodstve na osnove kompleksa selekcionno-geneticheskih metodov. Nauchnyj faktor $v$ strategii innovacionnogo razvitija svinovodstva: Sbornik materialov XXII Mezhdunarodnoj nauchno-prakticheskoj konferencii (g. Grodno, 9-11 sentjabrja 2015 g.). Grodno: GGAU, 91-99 (in Russian).

Orzechowskal, B., Tyra M., \& Koczanowski, J. (2006). Relationships between GPI and PGD loci genotypes and selected meat quality traits in Duroc and Pietrain pigs. Animal Science Papers and Reports, 22(4), 507-513.

Povod, M. H. (2014). Vplyv tekhnolohichnykh osoblyvostei na vidhodivelni pokaznyky svynei // Visnyk Sumskoho natsionalnoho ahrarnoho universytetu. Seriia "Tvarynnytstvo", 2(25), 194-200 (in Ukrainian).

Shcherbatyy, A. R., Slivinska, L. G., Gutyj, B. V., Fedorovych, V. L., \& Lukashchuk, B. O. (2019). Influence of Marmix premix on the state of lipid peroxidation and indices of non-specific resistance of the organism of pregnant mares with microelementosis. Regulatory Mechanisms in Biosystems, 10(1), 87-91. doi:10.15421/021914

Shejko, R. I., Bal'nikov, A. A., \& Mal'chevskij, A. V. (2013). Morfologicheskij sostav tush chistoporodnogo i pomesnogo molodnjaka svinej. Aktual'nye problemy intensivnogo razvitija zhivotnovodstva, 16(2), 105-111 (in Russian).

Slivinska, L., Fedorovych, V., Gutyj, B., Lychuk, M., Shcherbatyy, A., Gudyma, T., Chernushkin, B., \& Fedorovych, N. (2018). The occurrence of osteodystrophy in cows with chronic micronutrients deficiency. Ukrainian Journal of Ecology, 8(2), 24-32. doi: 10.15421/2018_305

Susol, R. L. (2013). Produktyvnist svynei velykoi biloi porody z pokrashchenymy miasnymy yakostiamy z urakhuvanniam DNK-markeriv. Naukovyi visnyk "Askaniia-Nova", 6, 229-235 (in Ukrainian).

Susol, R. L. (2013). Suchasni aspekty intensyfikatsii vyrobnytstva svynyny na Odeshchyni. Visnyk ahrarnoi nauky Prychornomoria, 4(2), 157-163 (in Ukrainian).

Susol, R. L. (2014). Produktyvni yakosti svynei suchasnykh henotypiv zarubizhnoi selektsii za riznykh metodiv rozvedennia $v$ umovakh Odeskoho rehionu. Visnyk Sumskoho natsionalnoho ahrarnoho universytetu. Seriia: Tvarynnytstvo, 2(2), $92-98$ (in Ukrainian).

Svechin, Ju. K. (1985). Prognozirovanie produktivnosti zhivotnyh v rannem vozraste. Vestnik s.h. nauki, 4, $103-108$ (in Russian).

Vlizlo, V. V., Fedoruk, R. S., \& Ratych, I. B. (2012). Laboratorni metody doslidzhen u biolohii, tvarynnytstvi ta veterynarnii medytsyni]: dovidnyk. Lviv: SPOLOM (in Ukrainian).

\section{Citation:}

Khalak, V., Gutyj, B., Bordun, O., Ilchenko, M., Horchanok, A. (2020). Effect of blood serum enzymes on meat qualities of piglet productivity. Ukrainian Journal of Ecology, 10(1), 158-161.

\begin{tabular}{|l|l}
\hline$(\mathrm{cc}) \mathrm{Br}$ & $\mathrm{Br}$ \\
\hline
\end{tabular} 